stances attaching to the chair almost preclude possibility to treat its subject as a province of experimental science. Physiology, inseparable from chemistry and physics, could, one might have imagined, at an Institution so fanous for the character of its lectures on those subjects, have been advantageously placed. That, from Prof. Waller's letter, is evidently the reverse of its present case at the Royal Institution. Not a workroom, even of the smallest size, could he obtain for conduction or preparation of his experiments. This must be a revelation to many who know the Institution as connected with the names of men, such as Davy and Faraday, who contributed by research to physiology - who, in other words, considered the chemistry and physics of living material as well as that of dead to lie within the scope of study and inquiry supported by the Institution. It is true that the Fullerian chair of Chemistry has proved fruitful in measure exceeding the productiveness of the Fullerian chair of Physiology. The latter has been declared comparatively sterile. This is regrettable; but its reason does not seem far to seek. Both chairs have been held by men of high distinction; but the former has rested upon a laboratory, while the latterso far from resting upon a laboratory- "does not possess even one small room in which to keep itself alive." Is this condition irremediable? I ask although by circumstance outside the Institution ; and ask simply as one interested in the welfare of physiological science, and as a unit of a public who esteen: the Institution as a place of instruction for the educated masses of a great city where at present such opportunities as the Institution offers are lamentably few.

Liverpool, December 3I, I897.

Ch. S. Sherrington.

\section{A Mechanical Theory of the Divining Rod.}

ThE review in NATURE (October 14,1897 , pp. 568, 569) of a publication relating to the "divining rod," recalls to my mind a purely mechanical theory of that rod, which was given me years ago by a friend.

This theory has been repeatedly tested by me and shown to be correct in the presence of my classes. The process is ex ceedingly simple. Take any forked twig of a reasonably tough fibre in the clenched hands with the palms upward. The ends of the limbs forming the twig fork should enter the closed fists on the exterior side of each fist, i.e. on the two sides of the clenched hands furthest from each other.

When a twig is grasped in this position it will remain stationary if held loosely, or with only a moderately firm grasp ; but the moment the grasp is tightened, the pressure on the branches will force the end of the twig to bend downwards. The harder the grip the more it must curve.

The curvature of the twig is mechanically caused by the pressure of the hands forcing the limbs to assume a bent and twisted position; or the force that causes the forked limb to turn downwards is furnished by muscles of the hands, and not from any other cause.

The whole secret of the "divining rod" seems to reside in its position in the hands of the operator, and in his voluntarily or involuntarily increasing the closeness of his grasp on the two ends of the branches forming the fork.

If the above conditions are fulfilled the twig will always bend downwards-water or no water, mineral or no mineral; any one can be an operator, and any material can be used for the instrument, provided the limbs forming the fork are sufficiently tough and flexible.

It can be easily understood how an ignorant operator may deceive himself, and be perfectly honest in supposing that some occult force, and not his hands, causes the fork to curve downwards.

Michigan College of Mines, Houghton, Michigan, December 8, I897.

Growth of the Tubercle Bacillus at a Low Temperature.

A BROTH culture of the tubercle bacillus a month old was filtered through a sterilised Berkfeld filter; the filtrate was ascertained to be sterile; it was then sown with a trace of $B$. tuberculosis and incubated at a temperature varying slightly between $18^{\circ}-20^{\circ} \mathrm{C}$., but never higher than $20^{\circ}$.

The bacillus developed well, but not so rapidly as at the customary temperature, i.e. $37^{\circ} 8^{\circ} \mathrm{C}$.; the growth had not the usual flocculent appearance, but was granular.

Microscopically the organism was unchanged.

London, December 20, 1897 .

F. J. REID.
THE STORY OF GLOUCESTER.

1979 cases of small-pox, 434 deaths; or a mortality of $2 \mathrm{I} \cdot 9$ per cent. during a period of thirteen months.

\begin{tabular}{|c|c|c|c|c|}
\hline Previously vaccinated & & $\begin{array}{r}\text { Cases. } \\
\text { I } 2 \text { II }\end{array}$ & $\begin{array}{l}\text { Deaths. } \\
\text { I } 20\end{array}$ & $\begin{array}{c}\text { Percentage } \\
\text { mortality. } \\
9.8\end{array}$ \\
\hline Unvaccinated $\quad \ldots$ & $\cdots$ & 768 & 314 & $40 \cdot 8$ \\
\hline & & 1979 & 434 & \\
\hline
\end{tabular}

SUCH, in brief, is the story told by Dr. Sidney Coupland in his Report to the Royal Commission on Vaccination on the outbreak of small-pox in the city of Gloucester in I $895-96$.

These figures, in all their baldness, convey a lesson such as no long garnished account can accentuate or emphasise ; but in Dr. Coupland's Report a number of most interesting facts and statistics have been brought together, which will form the basis of many future reports and arguments.

One of the most interesting points brought out, apart from the mortality, was the proportion of severe and mild cases in vaccinated and unvaccinated patients. Of those vaccinated in infancy, there suffered from-Per cent.

Malignant small pox 2.4 of the whole of those attacked.

Confluent ,, I9.I ,, ,

$\begin{array}{llll}\text { Coherent } & , & 9.6 & \text {,", }\end{array}$

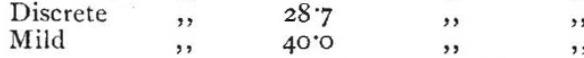

When we come to those who are said to have been vaccinated, but of which there is no very strong evidence, we find:-

Per cent.
Malignant small-pox $17^{\circ} 5$ of the whole of those attacked.

Confluent , , 52.5 ,

$\begin{array}{llrll}\text { Coherent } & , & 525 & , & , \\ \text { Discrete } & \text {," } & \text { 10.0 } & ,, & , \\ \text { Mild } & ,, & 75 & , ", & ,\end{array}$

Being a marked rise in malignant and a great fall in mild cases.

Amongst the unvaccinated the proportion of severity of attacks at all ages was :-

\begin{tabular}{llllllr}
\multicolumn{2}{l}{ Malignant small-pox } & $\ldots$ & $\ldots$ & $\ldots$ & $\ldots$ & $5 \cdot 0$ \\
Cunfluent &, & $\ldots$ & $\ldots$ & $\ldots$ & $\ldots$ & $72 \cdot 3$ \\
Coherent &, & $\ldots$ & $\ldots$ & $\ldots$ & $\ldots$ & $10 \cdot 3$ \\
Discrete &, & $\ldots$ & $\ldots$ & $\ldots$ & $\ldots$ & $8 \cdot 7$ \\
Mild & $\ldots$ & $\ldots$ & $\ldots$ & $\ldots$ & 3.6
\end{tabular}

Showing a very high percentage, indeed, of the severe type of case.

These figures are given in full because they afford evidence, quite apart from the mortality, of the enormous influence that vaccination exerts on the course of an attack of small-pox.

The Gloucester epidemic appears to have differed from almost every other recent outbreak of small-pox in the fact that its incidence was especially heavy on infants and young children. Below one year the proportion of deaths was no fewer than 14 per cent. of the whole, whilst at ages from I to Io years it was exceedingly heavy $-50^{\circ} 4$ per cent. This, of course, was accompanied by a corresponding diminution in the proportion of deaths at later years; and from io to 30 years the proportion had fallen to 12.6 per cent., though from 30 years and upwards (the effect of early vaccination having worn off to some extent) it had again risen to $22 \%$ When these figures are compared with the earlier outbreak of $1873-75$ in Gloucester and with the Dewsbury and Leicester outbreaks, it is found that the proportion of deaths amongst children is exceptionally high. It was noticed, too, that the disease spread amongst these children with enormous rapidity, and that it occurred amongst them in an exceptionally severe type, both as regards the proportion of malignant cases and the height of the mortality. 